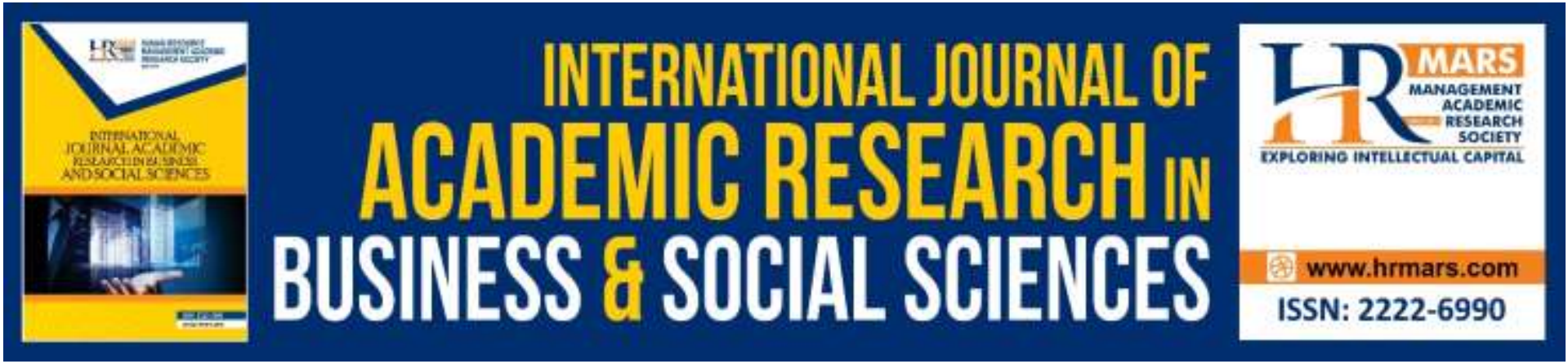

\title{
Customers Satisfaction and Service Quality of Islamic Banks in Perak, Malaysia
}

Amira Najiha Abu Bakar, Mohd Yahya Mohd Hussin, Nor Azrin Md Latip \& Ahmad Mahmood

To Link this Article: http://dx.doi.org/10.6007/IJARBSS/v9-i9/6461

DOI: $10.6007 /$ IJARBSS/v9-i9/6461

Received: 10 August 2019, Revised: 30 August 2019, Accepted: 01 September 2019

Published Online: 24 September 2019

In-Text Citation: (Bakar, Hussin, Latip, \& Mahmood, 2019)

To Cite this Article: Bakar, A. N. A., Hussin, M. Y. M., Latip, N. A. M., \& Mahmood, A. (2019). Customers Satisfaction and Service Quality of Islamic Banks in Perak, Malaysia. International Journal of Academic Research in Business and Social Sciences, 9(9), 1283-1297.

\section{Copyright: (C) 2019 The Author(s)}

Published by Human Resource Management Academic Research Society (www.hrmars.com)

This article is published under the Creative Commons Attribution (CC BY 4.0) license. Anyone may reproduce, distribute, translate and create derivative works of this article (for both commercial and non-commercial purposes), subject to full attribution to the original publication and authors. The full terms of this license may be seen at: http://creativecommons.org/licences/by/4.0/legalcode

\section{Vol. 9, No. 9, 2019, Pg. 1283 - 1297}

Full Terms \& Conditions of access and use can be found at http://hrmars.com/index.php/pages/detail/publication-ethics 


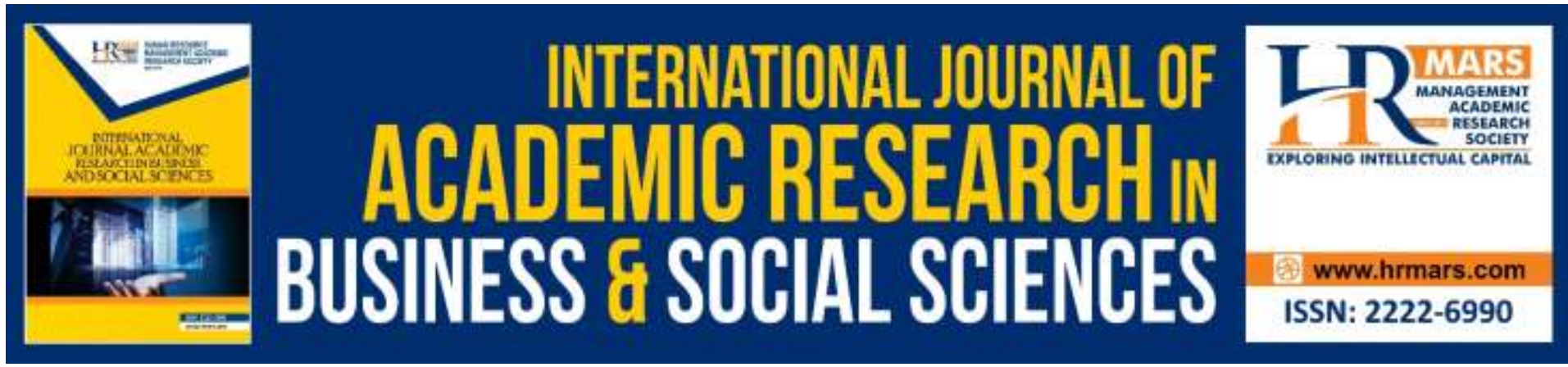

\title{
Customers Satisfaction and Service Quality of Islamic Banks in Perak, Malaysia
}

\author{
Amira Najiha Abu Bakar, Mohd Yahya Mohd Hussin, \\ Nor Azrin Md Latip \& Ahmad Mahmood \\ Universiti Pendidikan Sultan Idris, Tanjong Malim, Perak. Malaysia \\ Email: yahya@fpe.upsi.edu.my
}

\begin{abstract}
This study was aimed at analysing the customers' satisfaction level of the Islamic banking service quality as well as identifying the service quality elements which were linked to and influenced the customers' satisfaction level of Islamic banking in Perak, Malaysia. The CARTER model was utilised to achieve the study objectives. A total of 135 respondents had been chosen among the students of the Bachelor of Economy (Islamic Finance) programme, Sultan Idris Education University. The data acquired was then analysed using the descriptive and inferential methods to answer the study questions and to achieve the study objectives. The analysis showed that the customers' satisfaction level of Islamic banking service was at a high level. The correlational test conducted also showed that all the service quality elements tested indicated a positive and significant relationship with customers' satisfaction. The regression analysis results showed that the elements of tangible and compliance were the significant elements in influencing the customers' satisfaction of Islamic banking service quality in, Perak. As such, in order to ensure that the customer satisfaction level is always at a high level, the management of Islamic banking should avoid from being involved in any Syariah issues affecting their products or service. They should also ensure that the physical or external condition of the bank is clearly visible and is situated in a good location and that the electronic equipment such as ATM and CDM machines are always in a good condition and easy to use; this simplifies customer usage and enhances customer satisfaction.
\end{abstract}

Keywords: Customer Satisfaction, Service Quality, Islamic Banking.

\section{Introduction}

Malaysia is a Muslim country but not all banking institutions in Malaysia are operating according to Syariah principles. This is because Malaysia is an Islamic country with many ethnic groups with their own respective faiths. As such, in order to respect the views and the way of life of other ethnic groups, the Malaysian government allows both conventional banking and Islamic banking to be applied in the banking system. Furthermore, the first banking institution in Malaysia, The Chartered Merchant Bank of India, London and China, was based on the conventional banking system. At that time, there was no specific institution 
which applied Islamic Banking in Malaya. As such, the conventional banking system introduced by the British was applied in Malaya and it has been utilised ever since.

In recent years, Malaysian Muslims became aware of the conventional banking system which is contrary to Islamic principles and they voiced out their wish to have Islamic banking institutions which operates according to Syariah principles. The success of Islamic banking in the Middle East as well as other countries had prompted the Muslim community to urge the Malaysian government to set up banks which operate according to Islamic principles. Finally, with the cooperation of many parties, the first Islamic bank in Malaysia was established which was Bank Islam Malaysia Berhad. Its authorised capital was RM500 million and its paid-up capital was RM80 million. It started its operations in July 1983 (Borhan, 2001).

The Islamic banking system appears to be much in demand although it may not surpass the popularity of the conventional banking system in Malaysia. This may be due to the relatively young age of Islamic banking compared to conventional banking which has been in operation much earlier. In addition, conventional banking institutions are also operating in an Islamic window where conventional banks offer Islamic banking products to enrich their products offering. This may be seen as one of the methods used by conventional banking to compete with Islamic banking in such competitive market.

Therefore, to ensure that Islamic banking continues to grow and able to compete with conventional banking, the former should play a more active role in promoting and enhancing the image of Islamic banking by offering a more quality service. This is because service quality is an aspect which is very much focused upon by the customers and it is the key element for service providers to compete with one another. Fauzwadi, Abu Bakar and Nasri (2013) stated that the main factor which could ensure the success of a business organisation is the customers' satisfaction level. Therefore, the management of Islamic banking should ensure that customers' satisfaction should be at a high level.

One way in which the management of Islamic banking could improve on the customers' satisfaction level is by providing high quality service. This is because high service quality has been identified as a strategy which could upgrade the competitiveness and in turn improve the company's profit (Anggur et.al., 1999). This is proven by the studies conducted by Erol and El Bdour (1989) and Erol et.al (1990) which found that service quality was one of the reasons which drove customers to choose Islamic banking.

According to Le Blanc and Nguyen (1988), banks which are able to provide service which can fulfil the customers' needs and satisfaction and in turn are able to compete with other banking institutions can be considered as successful banks. As such, the management of Islamic banks should take this opportunity to compete with the conventional banks in order to provide high quality service which is able to fulfil customers' needs. Indirectly, this could give a good name and a positive image to Islamic Banking; consequently, this would also attract more customers to utilise products and service offered by the latter. If the service offered is not able to satisfy customers' needs, then it would only bring loss to the banks and existing customers would also move on to other banks which are able to satisfy their needs in getting the service needed (Altwijrya \& Abduh, 2013). 
Additionally, the ability of an organisation to continue its business can be seen in the services offered. Karatepe et al. (2005) stated that banks could provide a different edge in the services offered by providing a quality service which fulfils customers' needs in order for them to compete with other banks. As such, it is imperative for Islamic banking institutions to identify the elements which could influence customer satisfaction towards service quality to attract the public to utilise Islamic banking. This study therefore aims to identify and analyse the elements of service quality which could be focused on by the Islamic banking institutions especially in the Perak state as well as reflect the current status of customer satisfaction towards the services offered by Islamic banking institutions in the Perak state.

\section{Literature Review}

According to Aida (2008), customer satisfaction is one of the terms used to assess the extent to which customer expectations are met based on the products and services provided. In other words, customer satisfaction is the final part of customer assessment of a product or service to identify whether the product/service can fulfill or exceed the customer perceptions or otherwise.

Fayaz, Ebraheem and Ulfat (2017) in their study compared the analysis of customer satisfaction towards Islamic banking and conventional banking offered by selected banks in Saudi Arabia. The study involved the physical, service and security aspects offered by the banks. The analysis found that there was no difference in terms of customer satisfaction towards Islamic banking and conventional banking. This is because the customers for each bank prioritised on the physical and security aspects and the way the bank staff served the customers to ascertain the satisfaction level.

The study conducted by Anitha (2016) found that the respondents were satisfied with the overall quality provided by Islamic banking in Kuching. Faisal (2014) in his study looked at the satisfaction level of students at Kolej Universiti Islam Sultan Azlan Shah; these students were customers of Islamic banking institutions who had responded towards the service offered by Islamic banking. The study results showed that Islamic banking institutions in Malaysia offered a good service and they were pleased with the friendly attitude of the staff in the Islamic banking institutions in Malaysia.

Mazlinda (2006) in her study analysed customer satisfaction towards service quality in the Islamic banking system provided by 3 banks in Kuala Terengganu. The researcher had used the CARTER model which involved 26 items. The data acquired was then analysed using the econometric method which comprised descriptive, correlation and regression analysis to show the validity of the model used and to describe the relationship between customers' satisfaction with service quality. Based on the analysis of the findings, the researcher also provided some suggestions to improve on the service quality.

Anitha, Husni and Zaim (2017) looked at customer satisfaction towards the service quality of online banking and identified factors which influenced service quality. The researchers had applied the SERVQUAL model as an independent variable which comprised the tangible, trustworthiness, responsiveness and empathy factors in questionnaires distributed to 184 respondents. The findings showed that the customers were satisfied with 
the internet banking services provided, and the responsive factor was identified as the main factor which influenced customer satisfaction followed by the belief factor and the empathy factor. The tangible factor was not significant in determining customer satisfaction.

A working paper presented by Faisal and Rizal (2013) discussed the service quality theory according to the Islamic perspective. The authors also discussed the quality concept in service as well as service quality theories which had been constructed by previous academics. The authors also looked at the measurement used to measure service quality which was through the compliance, trustworthiness, competency, tangible and empathy elements. The results of the discussion indicated that all five dimensions were in line with the recommendations suggested by Islamic principles.

Abedniya and Zaeim (2011) conducted a study aimed at improving certain weaknesses in the Islamic banking service by looking at customer expectations and perceptions of the Islamic banking system in Malaysia. The researchers utilised the CARTER model to measure the service quality and to assess the existing gap between customer satisfaction and the six dimensions of the CARTER model which were used to identify how customers evaluated the service quality of Islamic banking. The study findings indicated that there were differences in terms of customer expectations and customer perceptions towards the six dimensions of the CARTER model. The inferential analysis conducted showed that there was a relationship between independent variables and dependent variables used in the study.

Ali, Abdullah and Dinar (2011) in their study looked at the banking service quality offered by Bank Shariah Mandiri (Garut branch) in Indonesia and its effect on customer satisfaction. The researchers utilised the CARTER model to measure the service quality of that particular bank. The findings showed that service quality very much affected customer satisfaction and the dimension which influenced customers the most was the dimension of compliance followed by assurance, empathy, trustworthiness and responsiveness while the least influence on customers came from the tangible dimension.

The findings of a study by Ismah, Husniyati, Anizah and Kamaruzaman (2009) found that the trustworthiness dimension was the most important dimension in influencing customers to choose Islamic banking institutions followed by the assurance and tangible factors. The least important dimension was empathy followed by responsiveness and compliance. The study findings also indicated that customer satisfaction towards the service quality dimension offered by each bank differed according to the banking institution.

Hossain and Leo (2009) in their study assessed the service quality offered by a banking institution in the Middle East specifically in Qatar. The researchers used the quantitative method whereby the data was collected using questionnaires distributed to 120 customers of 4 banks in Qatar. The researcher also used a model which had been introduced by Berry et.al., Parasuman et.al., Stafford and Zeithaml and Bitner. The findings showed that the customers had high expectations of the tangible dimension and low expectations of the competence dimension. 
Asma (2012) in her study looked at the relationship between service quality with customer satisfaction of Islamic banking in Pakistan, United Arab Emirates and United Kingdom. The researcher utilised the CARTER model which involved dimensions of compliance, assurance, trustworthiness, tangible, empathy and responsiveness as independent variable which could measure customer satisfaction. The findings informed us that the assurance, trustworthiness and empathy dimensions were significant in assessing customer satisfaction of Islamic banking in Pakistan and United Kingdom, while in United Arab Emirates; the assurance dimension was more significant in assessing customer satisfaction.

Abu Bakar, Fauzwadi, Hashim and Hisham (2005) in their study looked at the relationship between service quality with customer satisfaction involving customers of two main banks which practised the Islamic banking system: Bank Islam and Bank Muamalat. The findings showed that the customer satisfaction level and the service quality provided were at a high level. Based on the correlation test, all variables showed a significant relationship with customer satisfaction. Generally, the findings indicated that the customers were very pleased with the service quality provided by Islamic banking.

Fauzwadi, Abu Bakar and Nasri (2013) analysed the relationship between product quality and service quality towards customer satisfaction of Islamic banking. Product quality involved comfort and product availability factors, while the researchers used the CARTER model for service quality involving the compliance, assurance, empathy, tangible, responsiveness and trustworthiness factors. The descriptive analysis showed that the customers' satisfaction level of Islamic banking was high. The comfort and product availability elements as well as the compliance, assurance, empathy, tangible, responsiveness and trustworthiness factors showed a positive and significant relationship with customer satisfaction.

Ali and Syed (2015) studied the relationship between service quality with customer satisfaction of Islamic banking in Pakistan. The researchers adapted the SERVQUAL model and improved on it by adding a Syariah compliant model in the service context. The study involved 450 respondents who were customers of Islamic banking in Pakistan. The analysis showed that there was a positive and significant relationship between service quality with customer satisfaction. The findings showed that service quality was an aspect utilised to measure customer satisfaction of Islamic banking in Pakistan and the compliance element was the most important element in the model.

The findings of a study by Hossain (2015) found that service quality offered by a bank influenced customer satisfaction. This was because based on the descriptive analysis findings, frequency test, confirmatory factor analysis (CFA) and structural equation model (SEM) conducted by the researchers revealed that core products, delivery services, systematic human resources and social responsibility had a significant relationship with the customer satisfaction of Islamic banking in Bangladesh; systematic human resources and delivery services were the factors which most influenced customer satisfaction.

Noradiva, Noriah and Izzah (2015) looked at the relationship of customer service with the service quality offered by Islamic banking in Malaysia. The variables in the study involved 
the bank staff, bank image, the services and facilities offered. The data received was then analysed using econometric methods such as regression analysis and correlation. The findings indicated a positive relationship between customer satisfaction with service quality elements such as bank staff, bank image as well as the services and facilities offered by the bank.

Mohamed and Muneer (2015) conducted a study which looked at the service quality factors influencing customers' satisfaction level. The researchers applied the CARTER model in their study. The study involved 300 respondents who were customers of five Islamic banks in Bahrain. The data acquired were then analysed using the econometric method such as correlation analysis and regression analysis. The findings showed a positive relationship between six service quality dimensions utilised in the study with customer satisfaction of Islamic banking.

All six service quality dimension utilized in Zurani's (2014) study to analyse customers' satisfaction level of Ar-Rahn Permodalan Kelantan showed a significant relationship with customer satisfaction; the empathy factor was the most critical factor. Overall, the study showed that customers were pleased with the service quality provided by Ar-Rahn Permodalan Kelantan.

A study by Hayat, Khuram and Anam (2011) focused on five customer satisfaction dimensions which were dimension of responsiveness, efficiency, transaction security, competitive services and knowledge of bank staff on the products and services offered. The authors then utilised the hierarchy analysis process to identify the factors which determined customer satisfaction towards the service offered by Islamic banking and conventional banking. The analysis conducted showed a significant relationship between service quality dimension and satisfactory dimension for the customers of Islamic banking and conventional banking in the study.

\section{Research Methodology}

This study utilized the questionnaire adapted from Othman and Owen (2001) as the main instrument to acquire the data required. The questionnaire comprised three main parts which were sections $A, B$ and $C$. Section A covered the respondents' demographic information while section B covered six service quality elements such as compliance, assurance, trustworthiness, tangible, empathy and responsiveness involving 30 items. Section $C$ focused on questions related to customer satisfaction level of Islamic banking in general.

The study population involved the students of Bachelor in Economics (Islamic Finance) who were customers of the Islamic banking services offered by Bank Islam Malaysia Berhad and Bank Muamalat. The rationale for the choice of banks was attributed to the three banking systems utilised in Malaysia which were the full Islamic banking system, the conventional banking system and the dual system. Bank Islam Malaysia Berhad and Bank Muamalat were banking institutions which applied the full Islamic banking system for their products and services. This enabled the researchers to achieve the study objectives which looked at customer satisfaction towards service quality in Islamic banking. There were 135 respondents in this study. This number was adequate to represent a study population based on the sample size table introduced by Krejcie and Morgan (1970). 
Based on the Alpha statistical test results conducted using the IBM Statistical Package for Social Science (SPSS), the reliability value for the items used are as the following:

Table 1: Summary of the Item Reliability Test

\begin{tabular}{|l|c|}
\hline Item / Dimension & Cronbach's Alpha Value \\
\hline Compliance element & 0.77 \\
\hline Assurance element & 0.93 \\
\hline Trustworthiness element & 0.90 \\
\hline Tangible element & 0.90 \\
\hline Empathy element & 0.86 \\
\hline Responsiveness element & 0.94 \\
\hline Customer satisfaction level & 0.91 \\
\hline
\end{tabular}

This indicated that the instruments' reliability level was acceptable and considered high reliability according to Chua (2012) who stated that the reliability level of an item was considered low if it showed an alpha value of less than 0.6.

\section{Discussion of Results}

Table 2 shows the demographic distribution of respondents in the study, comprising gender, age, year of study, customer status and the names of banks.

Table 2: Demographics

\begin{tabular}{|c|c|c|}
\hline Item & Frequency & $\begin{array}{c}\text { Percentage } \\
\text { (\%) }\end{array}$ \\
\hline Gender & 38 & 28.1 \\
Male & 97 & 71.9 \\
Female & 49 & 36.3 \\
\hline Age & 86 & 63.7 \\
18-20 years old & 19 & 14.1 \\
21-23 years old & 46 & 34.1 \\
\hline Year of study & 21 & 15.6 \\
Year 1 & 49 & 36.3 \\
Year 2 & & \\
Year 3 & 135 & 100.0 \\
Year 4 & 0 & 0 \\
\hline Customer Status & & \\
Yes & 129 & 95.6 \\
No & 6 & 4.4 \\
\hline Bank Islam & 135 & 100 \\
\hline Bank Muamalat & &
\end{tabular}


The demographic distribution in this study was dominated by 97 female students while there were 38 male students and their age group was 18-23 years old. The respondents were from Year 1, 2, 3 and 4 without being dominated by any particular study year. 100 percent of respondents were customers of Islamic banking institutions. From the table we can ascertain that there were 129 respondents who were customers of Bank Islam (95.6 percent) and 6 respondents (4.4 percent) who were customers of Bank Muamalat. Both these institutions are full Islamic banking institutions.

The following are the findings of the descriptive analysis of the mean and standard deviation for customer satisfaction level and service quality offered by Islamic banking institutions.

Table 3: Mean and Standard Deviation for Customer Satisfaction Level and Service Quality in Islamic banking institutions

\begin{tabular}{|l|c|c|c|}
\hline Item & Mean & $\begin{array}{l}\text { Standard } \\
\text { Deviation }\end{array}$ & Interpretation \\
\hline Customer satisfaction level & 4.269 & 0.544 & High \\
\hline Compliance & 4.41 & 0.53 & High \\
\hline Assurance & 4.45 & 0.65 & High \\
\hline Trustworthiness & 4.40 & 0.57 & High \\
\hline Tangible & 4.25 & 0.62 & High \\
\hline Empathy & 4.29 & 0.61 & High \\
\hline Responsiveness & 4.33 & 0.68 & High \\
\hline
\end{tabular}

Based on Table 3 above, the mean value recorded for customer satisfaction level was high at 4.269 with a standard deviation of 0.544 . This clearly showed that the customer satisfaction level of the service offered by Islamic banking in Perak was at a high level. This finding was consistent with studies conducted by Metawa \& Almossawi (1998), Naser et al. (1999) and Anitha (2016) who found that the customer satisfaction level for Islamic banking was high and received very good response from the customers

In terms of service quality, the assurance element was the Islamic banking service quality element with the highest mean value at 4.45 with a standard deviation value of 0.65 , followed by the compliance element (4.41), trustworthiness (4.40), responsiveness (4.33), empathy (4.29) and tangible elements (4.25).As such, it could be concluded that all Islamic banking service quality element utilized in this study were important in assessing service quality offered by Islamic banking.

Based on the correlation analysis conducted, all service quality elements tested showed a positive and significant relationship with customer satisfaction level as shown in the table below. 
Table 4: Correlation between Customer Satisfaction Level with Islamic banking service quality element

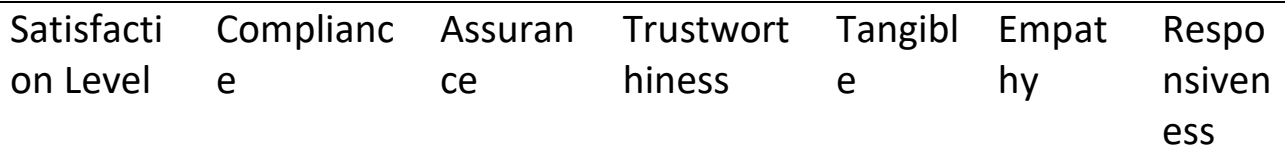

\begin{tabular}{|c|c|c|c|c|c|c|c|}
\hline $\begin{array}{l}\text { Satisfaction } \\
\text { level }\end{array}$ & 1 & & & & & & \\
\hline Compliance & $.330^{* *}$ & 1 & & & & & \\
\hline Assurance & $.408^{* *}$ & $.695^{* *}$ & 1 & & & & \\
\hline Trustworthines & $.478^{* *}$ & $.632^{* *}$ & $.791^{* *}$ & 1 & & & \\
\hline $\mathrm{s}$ & & & & & & & \\
\hline Tangible & $.681^{* *}$ & $.614^{* *}$ & $.627^{* *}$ & $.667^{* *}$ & 1 & & \\
\hline Empathy & $.633^{* *}$ & $.691^{* *}$ & $.621^{* *}$ & $.693^{* *}$ & $.860^{* *}$ & 1 & \\
\hline Responsiveness & $.511^{* *}$ & $.556^{* *}$ & $.651^{* *}$ & $.705^{* *}$ & $.698^{* *}$ & $.783^{* *}$ & 1 \\
\hline
\end{tabular}

$* *$ Significant at meaningful level of $1 \%$

The findings were consistent with the study by Anitha (2016) who found that all these elements were significant and positively related with customer satisfaction level. The findings were also supported by Abu Bakar et al. (2005) who found that the compliance element was the element with the lowest relationship compared to other service quality elements. The study by Faisal (2014) also showed that all elements were positively related with customer satisfaction level; however, the compliance element was the element with lowest relationship compared to other elements to the point that it was insignificant

The regression analysis was also conducted to identify whether the service quality elements in the study influenced the customer satisfaction level or otherwise. Table 5 shows the findings acquired from the regression analysis conducted.

Table 5: Regression analysis

\begin{tabular}{|l|l|l|l|}
\hline Model & beta & $\mathrm{t}$ & Sig. \\
\hline Constant & 1.913 & 6.147 & 0.000 \\
Compliance & -0.189 & -1.1933 & 0.055 \\
Assurance & -0.006 & -0.062 & 0.950 \\
Trustworthiness & 0.067 & 0.609 & 0.544 \\
Tangible & 0.475 & 4.249 & 0.000 \\
Empathy & 0.218 & 1.650 & 0.101 \\
Responsiveness & -0.008 & -0.086 & 0.931 \\
\hline R-Squared & 0.491 \\
Adjusted R-Squares & 0.467 & \\
F-Statistic & 20.564 \\
Durbin Watson & \multicolumn{3}{|l|}{1.956} \\
\hline
\end{tabular}


The regression analysis informed us that the tangible element was the element which influenced customer satisfaction level the most, whereby t was 4.249 at the significant level of $0.00(p<0.05)$. This indicated that the tangible element played an important role in influencing customer satisfaction level. The findings were in line with studies by Abdullah and Kassim (2009) and Bitner (1992) which stated that satisfaction from emotional, psychological, social and cognitive aspects could be created through a physical environment which could be seen with the naked eye. On the other hand, these findings were not in line with Anitha's (2016) study which found that the tangible element was not significant in influencing Islamic banking customers' satisfaction level in Kuching, Sarawak.

On the other hand, the compliance element showed a negative relationship in influencing customers' satisfaction level towards Islamic banking service quality where the beta value for the compliance element was -0.189 at $p=0.05$. This indicated that for every 1 percent increase in the compliance element, customer satisfaction towards the Islamic banking service would drop 18.8 percent at a meaningful level of 10 percent. However, this element had been identified as an important element in determining the service quality of Islamic banking; however, via the regression analysis, the element showed that it would affect customer satisfaction level negatively. This could be due to customers who utilized Islamic banking solely due to the religious factor but they were not very clear about the concepts and modus operandi applied in the Islamic banking system. These findings were consistent with studies by Ahmad and Haron (2002), Othman and Owen (2001), Haron et al. (1994) which stated that the religious factor played an important role in determining customer satisfaction regardless of religion or race.

The assurance and responsiveness elements also showed a negative relationship in influencing customers' satisfaction level where the beta value according to unstandardized coefficient for the assurance element was -0.006 and -0.008 for the responsiveness element. As for the trustworthiness and empathy elements, these showed a positive relationship in influencing customer satisfaction level whereby the trustworthiness element recorded a beta value of 0.067 and the empathy element showed a beta value of 0.218 . However, the assurance, trustworthiness and responsiveness elements were considered insignificant in influencing customer satisfaction level as the $p$ value recorded was bigger than $\alpha=(0.001)$, as $\alpha=(0.005)$. This was possible as the items used to measure the service quality element in this study could not explain why service quality could influence customer satisfaction towards the Islamic banking system. These findings were consistent with the study by Lassar et al. (2000) which stated that the empathy element was a critical element in determining customer satisfaction.

Generally, the results of the regression analysis were satisfactory for all the variables where the $R^{2}$ value obtained was equal to 0.491 , which explained that 49.1 percent of the total change in customer satisfaction level could be explained by the independent variables of the study: compliance, assurance, trustworthiness, tangible, empathy and responsiveness. Additionally, the F-statistic value showed a value of 20,564 where the value of $p=(0.000)$ was less than $\alpha(0.001)$. This meant that there were independent variables in the model which were estimated to significantly influence customer satisfaction at the 99 percent meaningful level. In other words, the model had been matched well. The Durbin-Watson test was also 
performed, and the results showed that the model did not have a positive autocorrelation problem with a test value of 1.956 .

\section{Conclusion and Suggestions}

The general conclusion from the discussion was that customers were pleased with service offered by the Islamic banking institutions in Perak, Malaysia. However, there was still some room for improvement so that the customer satisfactions mean score could be improved to a value of 5.00 as the highest mean value for customer satisfaction. Some of the ways to improve this would be by focusing on the tangible element in the service so that it could be emphasised to the customers. Based on the regression analysis conducted, the tangible element showed a very critical and significant role in influencing the customers' satisfaction level. Therefore, if the Islamic banking institution focuses on the tangible element in their service, then customer satisfaction could be increased.

Additionally, the management of Islamic banking is also advised to describe or provide a clear description to the customers about the modus operandi used for every product offered so that customers could understand the products clearly. This is because there are some customers who utilize the Islamic banking solely due to the religion factor without clearly understanding the modus operandi behind the promotion of the product, thus causing the compliance factor to influence the satisfaction level in a negative way. Preferably, the compliance factor should positively influence the level of customer satisfaction.

Furthermore, other service quality elements should not be ignored as all these show an important and significant relationship with customer satisfaction level based on the correlation analysis conducted. To conclude, it is hoped that the findings of this study will help to create awareness for Islamic banking in improving and upgrading the service quality offered. This is because high quality services can enhance customer satisfaction which is an asset for banks to compete in this competitive industry.

\section{Corresponding Author}

Mohd Yahya Mohd Hussin

Universiti Pendidikan Sultan Idris

Tanjong Malim, Perak. Malaysia

Email: yahya@fpe.upsi.edu.my

\section{References}

Abedniya, A., \& Zaeim, M. N. (2011). Measuring the Perceive Services Quality in the Islamic Banking System in Malaysia, International Journal of Business and Social Science 2(13), 122-135.

Bakar, A., Fauzwadi, Hashim, Hisham. (2005). Kualiti Perkhidmatan dan Kepuasan Pelanggan Dalam Perbankan Islam. Journal of Muamalat and Islamic Finance Research 2 (1), 151170.

Ahmad, N., \& Haron, S. (2002). Perception of Malaysian Corporate Customers towards Islamic Banking Products \& Services. International Journal of Islamic Financial Services 3 (4), 1-16. 
Aida, S. (2008). Model Kepuasan Pelanggan Bagi Laman Web E-Runcit. Projek Sarjana. Skudai: Universiti Teknologi Malaysia.

Ali, M., Syed, D. A. R. (2015). Measurement of Service Quality Perception and Customer Satisfaction in Islamic Banks of Pakistan: Evidence from modified SERVQUAL model. Retrieved from http://mpra.ub.uni-muenchen.de/64039/ MPRA Paper No.64039.

Ali, M., Syed, D. A. R. (2015). Measurement of Services Quality Perception and

Customer Satisfaction in Islamic Banks of Pakistan: Evidence from Modified SERVQUAL Model. Munich Personal RePEc Archieve, University Karachi

Ali, R. M., Abdullah, R., \& Dinar, M. K. (2011). The Influence of Service Quality Towards Customer Satisfaction of Islamic Sharia Bank. Australian Journal of Basic and Applied Sciences 5 (9), 1099-1104.

Altwijrya, O. I., \& Abduh, M. (2013). "Customer Satisfaction and Switching Behavior in Saudi Islamic Banks: An Exploratory study", Journal of Islamic Finance 2(2), 17-25.

Anggur, M. G., Nataraajan, R., \& Jahera, J. S. (1999). Service Quality in The Banking Industry: An Assessment in a Developing Economy, International Journal of Bank Marketing 17,: 116-123

Anitha, R. (2016). Kepuasan Pelanggan Terhadap Kualiti Perkhidmatan Perbankan Islam: Kajian ke atas Pelanggan Bank-bank Islam di Kuching, Sarawak. Tesis ljazah Doktor Falsafah, Universiti Malaya.

Anitha, R., Muhamad, H. H., \& Mohamad, Z. I. (2017). Perkhidmatan Perbankan Internet: Kajian Terhadap Kepuasan Pelangan. Labuan e-Journal of Muamalat and Society 11, 30-38.

Asma, A. R. (2012). Customer satisfaction and service quality in Islamic banking: A comparative study in Pakistan, United Arab Emirates and United Kingdom.Qualitative Research in Financial Markets 4(:2/3), 165-175.

Bank Negara Malaysia. (n.d.). Retrieved from www.bnm.gov.my

Berry, L., Parasuraman, A., \& Zeithmal, V. (1990). Five imperatives for Improving SQ, Sloan Management Review 29: 29-38.

Bigham, G. (1989). An Investigation of The Needs, Attitudes and Behaviour of The Youth Market with Respect To Financial Services. Manchester: Manchester School of Management.

Bitner, M. J. (1992). Servicesscape: The Impact of Surrounding on Customers and Employees. Journal of Marketing 56, 57-71.

Borhan, J. T. (2001). Sistem Perbankan Islam di Malaysia: Sejarah Perkembangan,

Prinsip dan Amalannya. Jurnal Usuluddin 4, 137-164.

Chua, Y. (2006). Kaedah Penyelidikan Buku 1. Kuala Lumpur: McGraw Hill Education.

Chua, Y. (2012). Asas Statistik Penyelidikan Buku 2 (2 ${ }^{\text {nd }}$ ed.). Kuala Lumpur: McGraw- Hill (Malaysia) Sdn.bhd

Dusuki, A. W., \& Abdullah, N. I. (2007) Why Do Malaysian Customers Patronoze Islamic Banks? International Journal of Bank Marketing 25, no.3: 143-160.

Erol, C., \& El-bdour, R. (1989). Attitude, Behavior and Patronage factors of bank Customers towards Islamic Banks. International Journal of Bank Marketing 7(6), 31-37.

Erol, C., Kaynak, E., \& El-Bdour, R. (1990). Conventional and Islamic Banks: Patronage Behavior of Jordanian Customers. International Journal of Bank Marketing 8(4), 25-35.

Faisal, M., \& Rizal, M. (2013). Kualiti Perkhidmatan Menurut Perspektif Islam. Kolej Universiti Islam Sultan Azlan Shah. 
Faisal, M. (2014). Kepuasan Pelajar Terhadap Kualiti Perkhidmatan Perbankan Islam di Malaysia. Tesis Sarjana, Universiti Malaya.

Fauzwadi, M. A., Bakar, A. H., \& Nasri, M. (2013). Hubungan Antara Kualiti Produk, Kualiti Perkhidmatan dan Kepuasan pelanggan dalam Perbankan Islam. IJMS 20(1), 185-202.

Fayaz, A. L., Ebraheem, M. A., \& Ulfat, R. B. (2017). Comparative Analysis of Customer Satisfaction towards Islamic and Conventional Banking: An Empirical Study from Saudi Arabia. International Review of Management and Marketing 7(1), 273-280.

Hayat, M. A., \& Khuram, S. B. (2011). Customer's criteria for Selecting an Islamic bank: Evidence from Pakistan. Journal of Islamic Marketing 2(1), 14-2.

Hossain, S. S. (2015). Measuring the Customer Satisfaction of Islamic Banking sector in Banglasdesh. ECOFORUM 4 (1), 290-299.

Hossain, M., \& Leo, S. (2009). Customer perception on services quality in retail banking in Middle east: The case of Qatar. International Journal of Islamic and Middle Eastern Finance and Management, 2(4), 338-350.

Ismah, O., Husniyati, A., Anizah, Z., Wan Edura, W. R., \& Kamaruzaman, J. (2009). Customers Satisfaction in Malaysian Islamic Banking. International Journal of Economics and Finance, 1(1), 197-202.

Karatepe, O., Yavas, U., \& Babakus, E. (2005). Measuring Services Quality of Banks: Scale Development and Validation. Journal of Retailing and Customer Services, 12(5), 73-83.

Krejcie, R., \& Morgan, D. (1970). Determining Sample Size for Research Activities. Educational and Psychological Measurement, 30, 607-610.

Lassar, W., Manolis, C., \& Winsor, R. (2000). Services Quality Perspective and satisfaction in Private Banking. International Journal of Bank Marketing, 18(4), 181-199.

Blanc, L. G., \& Nguyen, N. (1988). Customer's Perceptions of Services Quality in Financial Institutions. International journal of Bank Marketing, 6(4), 7-18.

Mazlinda. (2006). Analisis Kepuasan Pelanggan Terhadap Kualiti Perkhidmatan di Sistem Perbankan Islam: Kajian kes di Kuala Terengganu. Kertas Projek Ijazah Sarjana Muda, Kolej Universiti Sains dan Teknologi Malaysia.

Metawa, S., \& Almossawi, M. (1998). banking Behavior of Islamic Bank Customers: Perspective and Implications. International Journal of Bank Marketing, 16(7), 299-313.

Mohamed, A. J., \& Muneer, M. S. (2015). The Impact of Customer Services Quality on Customer satisfaction in Islamic Banking. Journal of Islamic Marketing 8(4), 595-604.

Noradiva, H., Noriah, M. I., \& Izzah, N. M. N. (2015). Customer Satisfaction on Islamic banking System. Journal of Economics, Business and Management 3 (1), 140-143.

Othman, A., \& Owen, L. (2001). Adopting and Measuring Customer Services Quality (SQ) in Islamic Bank: A Case study in Kuwait Finance House. International Journal of Islamic financial Services, 3(1).

Parasuraman, A., Zeithaml, V., \& Berry, L. (1985). A Concerptual Model of Service Quality and Its Implications for Future Research. Journal of Marketing 49 (4), 41-50.

Parasuraman, A., Zeithaml, V., \& Berry, L. (1988). SERVQUAL: A Multiple-Item Scale for Measuring Consumer Perceptions of Services Quality. Journal of Retailing, 64(1), $12-$ 40.

Parasuraman, A., Zeithmal, V., \& Berry, L. (1994). Reassessment of Expectations as a

Comparison Standard in Measuring Services Quality: Implication for Further Research. Journal of marketing, 58, 111-124. 
INTERNATIONAL JOURNAL OF ACADEMIC RESEARCH IN BUSINESS AND SOCIAL SCIENCES Vol. 9, No. 9, September, 2019, E-ISSN: 2222-6990 @ 2019 HRMARS

Zurani, S. (2014). Persepsi Kepuasan Pelanggan Terhadap Kualiti Perkhidmatan Ar-Rahn: Kajian Kes di Permodalan Kelantan berhad (PKB). Tesis Sarjana, Universiti Utara Malaysia. 